\title{
New acoustic and molecular data shed light on the poorly known Amazonian frog Adenomera simonstuarti (Leptodactylidae): implications for distribution and conservation
}

\author{
Thiago R. CARVALHO ${ }^{1,7 . *}$, Leandro J.C.L. MORAES ${ }^{2,8}$, Ariadne ANGULO ${ }^{3}$, \\ Fernanda P. WERNECK ${ }^{4}$, Javier ICOCHEA ${ }^{5} \&$ Albertina P. LIMA $^{6}$ \\ ${ }^{1}$ Laboratório de Herpetologia, Departamento de Biodiversidade e Centro de Aquicultura, \\ Universidade Estadual Paulista (UNESP), Rio Claro, SP, Brazil. \\ 2,4,6 Coordenação de Biodiversidade, Instituto Nacional de Pesquisas da Amazônia (INPA), \\ Manaus, AM, Brazil. \\ ${ }^{3,5}$ IUCN SSC Amphibian Specialist Group, Toronto, Canada. \\ ${ }^{7,8}$ These authors equally contributed to this study. \\ *Corresponding author: thiago_decarvalho@yahoo.com.br \\ 2Email: leandro.jclm@gmail.com \\ 33Email: aangulo@amphibians.org \\ ${ }^{4}$ Email: fewerneck@gmail.com \\ ${ }^{5}$ Email: javiericochea@gmail.com \\ ㅌEmail: lima@inpa.gov.br

\footnotetext{
${ }^{1}$ urn:1sid:zoobank.org:author:A1286A8F-C01A-421B-8135-A333D321AC95

${ }^{2}$ urn:lsid:zoobank.org:author:C10837F4-B3EF-401F-963B-A1EC285636E7

${ }^{3}$ urn:lsid:zoobank.org:author:812819A1-41EF-4CB5-A23E-BC19CC0ED7B9

${ }^{4}$ urn:lsid:zoobank.org:author:F4964B53-22D3-4B7B-A774-674C5F207A98

${ }^{5}$ urn:lsid:zoobank.org:author:59BD9040-E4A1-4B1D-8CC2-C4F1CA29D635

${ }^{6}$ urn:lsid:zoobank.org:author:5E06A4D8-79DC-42EB-86C2-CC6042314ED9
}

\begin{abstract}
Adenomera simonstuarti is a poorly known species complex inhabiting western Amazonia. Here we reevaluate the species diversity within this complex based on previously documented and newly acquired molecular and phenotypic data. We also redescribe the calling pattern of the nominal species based on the original recording (Peru) and a new recording (Brazil). Our results indicate eight geographically structured genetic lineages and the nominal species with a multi-note call pattern. This is the first association of calls and DNA sequence from a voucher specimen, thereby enabling the assignment of $A$. simonstuarti to one specific lineage within the complex. The multi-note call was not previously reported and represents an important additional diagnostic character within Adenomera. The geographic distribution of $A$. simonstuarti is substantially narrowed down to the southwestern portion of the entire geographic range recognized for the complex. The lack of taxonomic resolution in the complex is a major conservation concern by preventing us from evaluating the potential threats and extinction risks of each of the lineages. Future research should follow the protocol of combining calls and DNA sequences associated with voucher specimens as a means to address the taxonomic status of genetic lineages within the $A$. simonstuarti complex.
\end{abstract}


Keywords. Acoustic diagnosis, Adenomera andreae clade, Amazon Basin, cryptic diversity, western Amazonia.

Carvalho T.R., Moraes L.J.C.L., Angulo A., Werneck F.P., Icochea J. \& Lima A.P. 2020. New acoustic and molecular data shed light on the poorly known Amazonian frog Adenomera simonstuarti (Leptodactylidae): implications for distribution and conservation. European Journal of Taxonomy 682: 1-18.

https://doi.org/10.5852/ejt.2020.682

\section{Introduction}

Morphologically indistinguishable species (cryptic species) have challenged taxonomists and systematists across several taxonomic groups (Bickford et al. 2007). This evolutionary trend occurs when speciation generates distinction in one or more biological traits, for instance, molecular, acoustic or ecological characters, but there is no or very subtle morphological differentiation (Cherty et al. 1978). High levels of cryptic species have been documented for many Neotropical frog groups, especially over the past decades (e.g., Fouquet et al. 2007, 2016; Padial \& De la Riva 2009; Simões et al. 2010; Jungfer et al. 2013). Understanding and conserving biodiversity levels, partly hidden in complexes of cryptic species, in such a megadiverse region strongly depends on the continued investigation of multiple sources of information to be compared with morphological variation (Padial et al. 2010).

A striking example of a Neotropical frog group with predominance of cryptic species is the genus Adenomera Steindachner, 1867 (e.g., Angulo \& Reichle 2008; Carvalho \& Giaretta 2013a; Carvalho et al. 2019a, 2019b). These small-sized leptodactylids (snout-vent length up to $34 \mathrm{~mm}$; Kok et al. 2007) are widely distributed in South America east of the Andes, currently comprising 21 described species (Carvalho et al. 2019b). A phylogenetic study of the genus based on a comprehensive geographic sampling revealed many putative new species, reported as candidate species (Fouquet et al. 2014). Some of these nominal and candidate species of Adenomera exhibit marked genetic divergence among populations and some of them are also known to have distinct call patterns, suggesting extensive cryptic diversity within the genus (Fouquet et al. 2014; Carvalho et al. 2019c, 2019d). Fouquet et al. (2014) classified the species diversity of Adenomera into eight major clades, one of them being the Amazonian endemic $A$. andreae clade. This clade contains three described species, $A$. andreae (Müller, 1923), A. chicomendesi Carvalho, Angulo, Kokubum, Barrera, Souza, Haddad \& Giaretta, 2019, and A. simonstuarti (Angulo \& Icochea, 2010), plus three candidate species reported as Adenomera sp. C, Adenomera sp. D, and Adenomera sp. T (Fouquet et al. 2014; Carvalho et al. 2019b).

Adenomera simonstuarti was described from Camisea (Province of La Convención, District of Echarate, Region of Cusco), a region of lowland forest in southwestern Peruvian Amazonia, based on a series of four specimens, and two referred specimens from Pando, in northern Bolivia (Angulo \& Icochea 2010). A few years later, Fouquet et al. (2014) showed, based on molecular evidence, that the species could actually be more widely distributed throughout lowland forests of western Amazonia and Andean montane forests, even though those authors also mentioned in their taxonomic considerations (see Fouquet et al. 2014: appendix S2a) that the deep genetic subdivisions within A. simonstuarti could suggest the existence of more than one species under the nominal species. A major limitation that holds back researchers to advance in the taxonomic resolution of this species complex is the lack of associated phenotypic and molecular data for the nominal species. Specimens have to date been identified as A. simonstuarti based on morphological and geographical data. Moreover, the only call description available is from the holotype in the original description, from which tissue samples were not collected (and neither were they collected from paratypes). It is important to highlight that species identification within Adenomera should be treated with caution in such cases which acoustic and/or molecular data 
are not available in a frog genus having a notably high number of undescribed and/or cryptic species (Carvalho \& Giaretta 2013a; Fouquet et al. 2014; Carvalho et al. 2019b; Cassini et al. 2020).

Here, we reevaluate the species diversity within the Adenomera simonstuarti complex by combining novel acoustic and molecular data, enabling for the first time that the nominal species could be linked to a specific genetic lineage within the complex. We also reinterpret the calling pattern of $A$. simonstuarti based on the original recording from the type locality in Peru and a new recording from the Brazilian Amazonia. Lastly, we discuss on the implications for distribution and conservation status of the genetic lineages subsumed under A. simonstuarti across their entire geographic range, resulting from the circumscription of the nominal species to one specific lineage.

\section{Material and methods}

\section{Taxon sampling and identification}

We collected five individuals of Adenomera that we associated with A. simonstuarti based on morphology, color patterns, and/or call characteristics, as follows: (1) tips of toes II-IV developed into discs (character state D; sensu Carvalho et al. 2019d); (2) presence of nearly solid, dark-colored stripe on the underside of forearm (sensu Angulo \& Icochea 2010); (3) advertisement call consisting of short-lasting $(<80$ $\mathrm{ms})$, pulsed notes with the dominant frequency generally coinciding with the fundamental harmonic (Angulo \& Icochea 2010). Specimens were euthanized using a topical solution of $10 \%$ lidocaine, fixed with 10\% formalin and preserved in 70\% ethanol. Voucher specimens were deposited in the Collection of Amphibians and Reptiles of the Instituto Nacional de Pesquisas da Amazônia (INPA-H) in Manaus (Amazonas, Brazil). These newly collected specimens were obtained from two localities along the Juruá River drainage in southwestern Brazilian Amazonia: (1) Unidade de Gestão Integrada (UGAI) Rio Acurauá, in the upper Juruá River, Tarauacá, Acre $\left(7.792320^{\circ} \mathrm{S}, 71.013968^{\circ} \mathrm{W}\right.$; in all cases datum =WGS84; on 12 Jan. 2019), accession number: INPA-H 40967; and (2) Comunidade Cumaru, Reserva Extrativista (RESEX) do Baixo Juruá, on the east bank of the lower Juruá River, Juruá, Amazonas (3.756961-3.825022 ${ }^{\circ} \mathrm{S}, 66.077231-66.083067^{\circ} \mathrm{W}$; on $\left.17-23 \mathrm{Jul} .2018\right)$, accession numbers: INPA-H 39792, 39796, 39813-39814. Specimens morphologically examined in this study are listed in Results. Institutional acronyms follow Sabaj (2019).

\section{Molecular analysis}

Genomic DNA was extracted from muscle and liver tissues preserved in $100 \%$ ethanol from three specimens (INPA-H 39792, 39814 and 40967) using standard protocols of a commercial kit (Wizard ${ }^{\circledR}$, Promega, Madison, USA). We sequenced a fragment of the mitochondrial gene cytochrome $c$ oxidase subunit I (COI; $657 \mathrm{bp}$ ), a widely used molecular marker for this frog group (Fouquet et al. 2014; Lyra et al. 2017). The primers CHmL4 (5-TYTCWACWAAYCAYAAAGAYATCGG-3) and CHmR4 (5-ACYTCRGGRTGRCCRAARAATCA-3) (Che et al. 2012) were used to perform amplification of the selected fragment via Polymerase Chain Reaction (PCR). The amplification reactions used a mix with $1.2 \mu \mathrm{L}$ of $10 \mathrm{mM}$ dNTPs, $3 \mu \mathrm{L}$ of a $5 \mathrm{X}$ amplification buffer, $1.2 \mu \mathrm{L}$ of $25 \mathrm{mM} \mathrm{MgCl}, 1.0 \mu \mathrm{L}$ of DNA in a concentration of $50 \mathrm{ng} / \mu \mathrm{L}, 0.5 \mu \mathrm{L}$ of each primer at $10 \mathrm{mM}, 0.15 \mu \mathrm{L}$ of Taq DNA polymerase and $7.45 \mu \mathrm{L}$ of $\mathrm{ddH}_{2} \mathrm{O}$. Reaction conditions began with an initial heating step at $94^{\circ} \mathrm{C}$ for $60 \mathrm{~s}$, followed by 35 cycles of denaturation at $94^{\circ} \mathrm{C}$ for $20 \mathrm{~s}$, annealing at $50^{\circ} \mathrm{C}$ for $50 \mathrm{~s}$ and extension at $72^{\circ} \mathrm{C}$ for $90 \mathrm{~s}$, followed by a final extension at $72^{\circ} \mathrm{C}$ for $10 \mathrm{~min}$. PCR products were purified with polyethylene glycol 8000, submitted to a sequencing reaction following BigDye Terminator Cycle Sequencing Kit (Applied Biosystems, Waltham, USA) protocols, and sequenced with an ABI 3130 XL automated sequencer (Applied Biosystems, Waltham, USA). These laboratory procedures were conducted in the Thematic Laboratory of Molecular Biology of INPA. We used Geneious 7 (Kearse et al. 2012) for sequence editing. 
Taxon sampling for the molecular analysis included each candidate new species and operational taxonomic units of nominal species from the eight major clades delimited by Fouquet et al. (2014), including all those identified therein as $A$. simonstuarti, as well as sequences from related genera to be used as outgroups (Lithodytes Fitzinger, 1843, Hydrolaetare Gallardo, 1963 and Leptodactylus Fitzinger, 1826). Besides the mtDNA gene COI, we downloaded additional sequences from another mtDNA gene (cytochrome $\mathrm{b}-c y t b ; 607 \mathrm{bp}$ ) and two nuclear genes (proopiomelanocortin $\mathrm{A}-\mathrm{POMC}$ and recombination activating gene $1-R A G 1 ; 547$ and $1422 \mathrm{bp}$, respectively) from the online repository GenBank (Clark et al. 2016). Accession numbers and other information of sequences included in the molecular analysis are provided in the Supplementary File SM.01. New sequences produced for this study were deposited in GenBank under the accession numbers MT472180-MT472182. We used MAFFT 7 online (Katoh \& Standley 2013) to independently align the sequences of each gene under the G-INS-i strategy, more suited for protein coding genes (Katoh \& Standley 2013). All genes were posteriorly concatenated, leading to a final aligned database containing 105 sequences and $3233 \mathrm{bp}$. We divided the dataset considering first, second, and third positions of the codon of each gene, and conducted the search for the best-fitting substitution models and partition schemes with PartitionFinder 2.1.1 (Lanfear et al. 2017) under the corrected Akaike information criterion (AICc; Hurvich \& Tsai 1989). Best scheme indicated five partitions, with the general time-reversible model (GTR; Tavaré 1986) with a gamma distribution of rates across sites $(+\mathrm{G})$ as the best-fitting nucleotide substitution model for the first and third position of cytb, and third position of POMC and $R A G 1$, whereas the $\mathrm{GTR}+\mathrm{G}$ with a proportion of invariant sites $(+\mathrm{I})$ was indicated as the best-fitting nucleotide substitution model to remaining codon positions (all from $C O I$, first and second of $P O M C$ and $R A G 1$, and second and third of $c y t b)$.

We reconstructed phylogenetic trees using both Bayesian inference (BI) and maximum likelihood (ML) optimality criteria. For the Bayesian analysis we used two independent runs of $5.0 \times 10^{7}$ generations, starting with random trees and four Markov chains (one cold), sampled every 10000 generations in MrBayes 3.2.6 (Ronquist et al. 2012), discarding 25\% of generations and trees as burn-in. We used the standard deviation of split frequencies $(<0.01)$ and estimated sample size $(>200)$ to assess run convergence with Tracer 1.7 (Rambaut et al. 2018). We conducted maximum likelihood analysis using RaxML 8.2.10 (Stamatakis 2014), searching the most likely tree 100 times and with 1000 non-parametric bootstrap replicates to assess support.

We used Mega 7 (Kumar et al. 2016) to compute the uncorrected and corrected (Jukes-Cantor model) pairwise genetic distances of the COI fragment among specimens of Adenomera simonstuarti missing data removed using pairwise deletion option. Both uncorrected and corrected genetic distances were considered for our study in order to increase accuracy and comparability of results. With the Approximate Barcode Gap Discovery method (ABGD, Puillandre et al. 2012), we conducted an analysis to delimit lineages of $A$. simonstuarti based on comparisons of uncorrected intra- versus interspecific genetic distances in $C O I$. The analysis were run at the ABGD online server using a prior of intraspecific divergence $(\mathrm{P})$ between 0.001 and 0.1 , a proxy for minimum relative gap width $(\mathrm{X})$ of 0.5 , and a number of bins (n) of 30. Based on an intraspecific divergence of $1 \%$, a recognized threshold in delineation analysis among vertebrate groups and the end of a plateau for lineage number (Puillandre et al. 2012), we considered the $16^{\text {th }}$ partition to delineate lineages.

\section{Acoustic analysis}

We recorded the advertisement call of one male $A$. simonstuarti from the upper Juruá River (see locality \#1 earlier) using a Sony PCM-DC50 digital recorder (sampling rate $=44.1 \mathrm{kHz}$; bit depth $=16$ ) and built-in microphones. The recording was stored as stereo-channel wave file (left channel was kept for the acoustic analysis). The sound recording was deposited in Fonoteca Neotropical Jacques Vielliard (Unicamp, Brazil) under the accession number FNJV 45412. Information on the recording 
is as follows: individual recorded at $09.40 \mathrm{~h}$ in the morning; air temperature around $25^{\circ} \mathrm{C}$. We also reanalyzed some of the original calls recorded from the type locality (Angulo \& Icochea 2010) in order to allow direct and standardized comparisons (FNJV 45409-11). We analyzed calls using an interface built between an expanded version (0.9.6.1) of Soundruler (Gridi-Papp 2007) and Matlab 6.5.2 (Matlab 2004). Note rate was quantified manually in Audacity 2.1.1 (Audacity Team 2017). Acoustic definitions and terminology follow those of Carvalho et al. (2019b). Acoustic traits were quantified through automated analysis, for which we developed settings in the software to recognize and delimit the acoustic units both in the time and frequency domains. Data are presented as range (mean \pm standard deviation). Ranges include the span of values from the raw dataset. In the case of pulse duration, given that acoustic signals analyzed had more than one pulse, we first averaged the duration of each pulse of a given note (call mean) and then obtained the averaged mean for each male analyzed from the mean duration of call pulses (individual mean), and lastly, we obtained the grand means and associated standard deviations by averaging individual means. We applied two bandpass (500-Hz high-pass and/or 5000-Hz low-pass) filters to some of the sound files in Soundruler prior to conducting the acoustic analysis to reduce background noise caused by wind and/or rain. Spectrogram parameters were set as follows: FFT size $=1024$ points, FFT overlap $=90 \%$, window type $=$ Hanning, contrast $=70 \%$; those for the automated analysis were (in sample sizes): detection (smoothing $=500$, resolution $=1$ ), delineation (smooth factor $=1$, smoothing $=15$ or 100 , and resolution $=1$ ); critical amplitude ratio $=0.8$ or 1.0. We produced sound figures using seewave 2.1.0 (Sueur et al. 2008) and tuneR 1.3.2 (Ligges et al. 2017), in R 3.5.0 (R Core Team 2018). Spectrogram settings were: window Hanning, FFT size $=256$ points, and FFT overlap $=90 \%$; the level of frequency components was indicated by a relative $30-\mathrm{dB}$ color scale (red = maximum energy).

\section{Results}

Order Anura Fischer von Waldhein, 1813

Family Leptodactylidae Werner, 1896

Subfamily Leptodactylinae Werner, 1896

Genus Adenomera Steindachner, 1867

Adenomera simonstuarti (Angulo \& Icochea, 2010)

\section{Material examined}

\section{Holotype}

PERU • Cusco, La Convención, Echarate, Río Camisea; MUSM 18218.

\section{Paratypes}

PERU • 3 specs; same collection data as for holotype; MUSM 18220, 18221, 18229.

\section{Other material}

BRAZIL • 1 spec., Acre, Tarauacá; INPA-H 40967 • 5 specs; Amazonas, Juruá; INPA-H 5337, 39792, 39796, 39813, 39814.

\section{Comparative material}

Adenomera andreae (Müller, 1923)

BRAZIL • 3 specs; Amapá, Serra do Navio; AAG-UFU 5994, 6006, 6007 • 2 specs; same collection data as for preceding; CFBH 43259, $43265 \cdot 11$ specs; Amazonas, Manaus; INPA-H 34045, 34048, 34073, 34074, 34076, 34081, 34082, 34084 to 34086,34090 - 5 specs; same collection data as for preceding; ZUEC 3937, 3969, 3973, 3974, 7799 • 2 specs; Pará, Belém; AAG-UFU 2797, 2798 • 7 specs; Nova Timboteua; AAG-UFU 2788 to 2794. 
Adenomera chicomendesi Carvalho, Angulo, Kokubum, Barrera, Souza, Haddad \& Giaretta, 2019 BRAZIL • holotype; Acre, Rio Branco, Parque Zoobotânico; CFBH $43562 \cdot 3$ specs, paratypes; same collection data as for holotype; AAG-UFU 5862 to $5864 \cdot 1$ spec., paratype; same collection data as for holotype; CFBH 43563 - 4 specs, paratypes; same collection data as for holotype; ZUEC 24528 to 245231.

PERU - 7 specs, paratypes; Madre de Dios, Reserva Nacional de Tambopata; MUSM 39462, 30463, $39467,39468,39472$ to 39474 .

Adenomera heyeri Boistel, Massary \& Angulo, 2006

BRAZIL • 3 specs; Pará, Oriximiná, ESEC-Grão-Pará; MPEG 30099 to 30101.

Adenomera hylaedactyla (Cope, 1868)

BRAZIL • 5 specs; Acre, Cruzeiro do Sul; AAG-UFU 5907 to 5911 • 3 specs; Feijó; AAG-UFU 5895 to 5897 - 8 specs; Amazonas, Manaus; INPA-H 22410 to 22413, 26606 to $26609 \cdot 8$ specs; São Gabriel da Cachoeira; AAG-UFU 3859 to 3866 • 4 specs; Roraima, Cantá; AAG-UFU 5540 to 5443.

Adenomera lutzi Heyer, 1975

GUYANA • 6 specs; Potaro-Siparuni; MZUSP 150799 to 150804.

Adenomera phonotriccus Carvalho, Giaretta, Angulo, Haddad \& Peloso, 2019

BRAZIL • holotype; Pará, Palestina do Pará; MPEG $41155 \cdot 2$ specs, paratypes; same collection data as for holotype; CFBH 43130, $43131 \cdot 1$ spec., paratype; same collection data as for holotype; MPEG 41156.

Adenomera sp. (A. andreae clade)

PERU • 1 spec.; Cusco, La Convención, Echarate, Río Camisea; MUSM 18219.

\section{Phylogenetic relationships and genetic diversity}

Both BI and ML phylogenetic reconstructions (Fig. 1) yielded similar results with regard to relationships in the Adenomera andreae clade and the monophyly of $A$. simonstuarti. All three new sequences from southwestern Brazilian Amazonia were recovered nested within A. simonstuarti (Fig. 1). The ABGD delimitation analysis recovered eight genetic lineages within A. simonstuarti (Fig. 2) with noticeable geographic structure (Figs 1-2). Mean genetic distances in COI among the lineages of $A$. simonstuarti (Table 1) range from 3.2-7.6\% (uncorrected) and from 3.3-8.0\% (corrected), whereas within-lineage genetic distances reach a maximum value of $1.7 \%$ (uncorrected and corrected).

Our genetic voucher INPA-H 40967 (Fig. 3) is the only specimen of Adenomera simonstuarti with associated acoustic data. Morphological and color features of the specimen fully agree with those presented in the original description of $A$. simonstuarti (Angulo \& Icochea 2010). This voucher specimen from the upper Juruá River constitutes the lineage 3 together with other specimens from the upper Amazon basin in southwestern Amazonia (Figs 1-2). The lineage 3 is regarded hereinafter as conspecific with the nominal species. The other two new COI sequences (lower Juruá River) fell within the lineage 2 . These two vouchers also have the recognized morphotype of $A$. simonstuarti (Fig. 4), but acoustic data for this lineage remain unknown. Mean genetic distances between the $C O I$ lineages 2 and 3 are noticeable, ranging from $5.0 \%$ (uncorrected) to $5.3 \%$ (corrected).

\section{Advertisement call and acoustic diagnosis}

The call of Adenomera simonstuarti (Fig. 5) is redescribed below based on combined values of calls recorded from southwestern Amazonia: the type locality (Camisea, Cusco, Peru) and the upper Juruá 


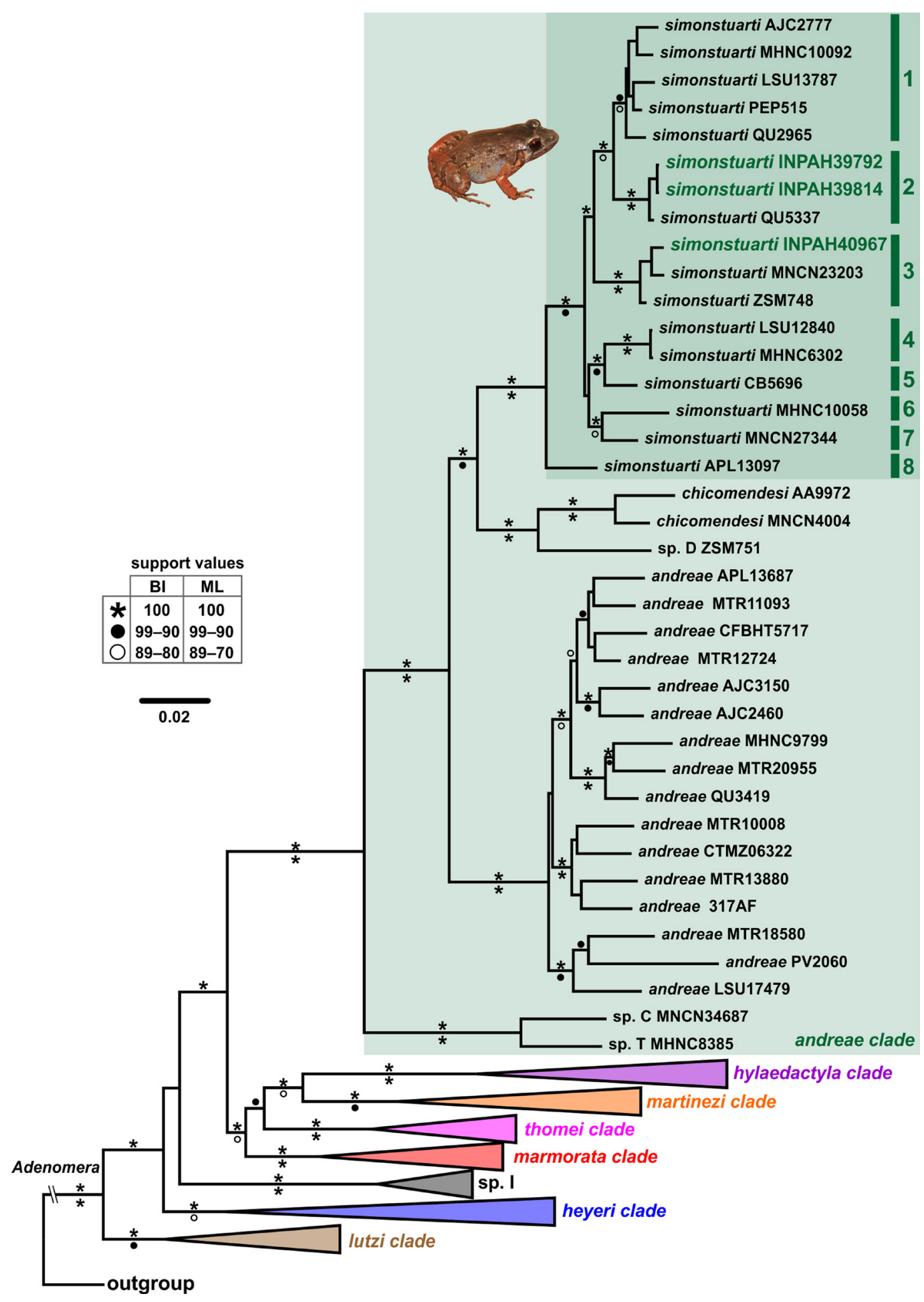

Fig. 1. Bayesian phylogenetic tree of Adenomera Steindachner, 1867 inferred from a concatenated dataset of four genes (two mitochondrial + two nuclear), showing the eight major clades delimited by colors. The emphasis on the diversification within the A. simonstuarti species complex shows a deep genetic divergence, with eight distinct lineages (see Fig. 2 for geographic distribution). Symbols above branches indicate posterior probabilities of Bayesian inference (BI) and those below branches indicate bootstraps of maximum likelihood inference (ML). Low support values $(\mathrm{BI}<80$ and $\mathrm{ML}<70)$ were omitted. Branch scale is indicated in number of substitution per site. 
Table 1. Uncorrected (lower diagonal) and corrected (Jukes-Cantor model; upper diagonal) pairwise genetic distances of a fragment from COI mtDNA gene among the lineages of the Adenomera simonstuarti species complex (named as sim1-8). Within-lineage distances (uncorrected/corrected), when applicable, were highlighted in bold across the central diagonal (upper left to lower right). The lineage 3 corresponds to the nominal species. Values are presented as means (in \%).

\begin{tabular}{|c|c|c|c|c|c|c|c|c|}
\hline & $\operatorname{sim} 1$ & $\operatorname{sim} 2$ & $\operatorname{sim} 3$ & $\operatorname{sim} 4$ & $\operatorname{sim} 5$ & $\operatorname{sim} 6$ & $\operatorname{sim} 7$ & $\operatorname{sim} 8$ \\
\hline $\operatorname{sim} 1$ & $1.7 / 1.7$ & 3.3 & 5.2 & 6.1 & 4.8 & 5.9 & 4.3 & 6.9 \\
\hline $\operatorname{sim} 2$ & 3.2 & $0.2 / 0.2$ & 5.3 & 7.0 & 5.4 & 5.8 & 5.4 & 7.2 \\
\hline $\operatorname{sim} 3$ & 4.9 & 5.0 & $0.7 / 0.7$ & 5.3 & 4.7 & 5.1 & 5.2 & 7.3 \\
\hline $\operatorname{sim} 4$ & 5.8 & 6.7 & 5.1 & $0.0 / 0.0$ & 3.8 & 7.3 & 5.6 & 8.0 \\
\hline $\operatorname{sim} 5$ & 4.6 & 5.2 & 4.5 & 3.7 & - & 6.1 & 3.9 & 7.1 \\
\hline $\operatorname{sim} 6$ & 5.7 & 5.6 & 5.0 & 7.0 & 5.9 & - & 6.0 & 7.5 \\
\hline $\operatorname{sim} 7$ & 4.2 & 5.2 & 5.0 & 5.3 & 3.8 & 5.8 & - & 6.7 \\
\hline $\operatorname{sim} 8$ & 6.6 & 6.9 & 7.0 & 7.6 & 6.8 & 7.1 & 6.3 & - \\
\hline
\end{tabular}

Table 2. Advertisement call traits of Adenomera simonstuarti (Angulo \& Icochea, 2010) from southwestern Amazonia of Peru (type locality) and Brazil. One male was recorded from each locality. $\mathrm{N}=$ number of quantified notes and pulses, respectively. Values are presented as range (mean $\pm \mathrm{SD}$ ).

\begin{tabular}{lcc}
\hline Acoustic traits & Camisea (Cusco, Peru) & Tarauacá (Acre, Brazil) \\
\hline Call duration (s) & $\mathbf{N}=\mathbf{3 3} / \mathbf{9 8}$ & $\mathbf{N}=\mathbf{2 4} / \mathbf{5 5}$ \\
Notes per call & $0.8-5.1(2.1 \pm 1.8)$ & $1.5-6.5(4.8 \pm 1.7)$ \\
Note duration (ms) & $4-20(8.6 \pm 6.7)$ & $8-30(22.6 \pm 7.6)$ \\
Note rate per second & $57-71(64.7 \pm 3.4)$ & $62-79(68.5 \pm 4.5)$ \\
Note rise time (\%) & $3.7-4.1(3.8 \pm 0.1)$ & $4.5-4.9(4.6 \pm 0.1)$ \\
Pulses per note & $13-73(33.5 \pm 14.0)$ & $20-60(38.1 \pm 16.2)$ \\
Pulse duration (ms) & $2-3(3.0 \pm 0.2)$ & $2-3(2.3 \pm 0.5)$ \\
Dominant frequency $(\mathrm{Hz})$ & $10-31(21.8 \pm 2.3)$ & $10-53(30.9 \pm 5.8)$ \\
Frequency modulation $(\mathrm{Hz})$ & $1873-2003(1958.2 \pm 20.1)$ & $1873-2046(1961.7 \pm 56.7)$ \\
\hline
\end{tabular}

River (Tarauacá, Acre, Brazil) (Table 2). The call consists of a multi-note signal given at a low repetition rate $(<10$ per minute), lasting 0.8-6.5 $(3.4 \pm 1.9) \mathrm{s}$. Calls are formed by $4-30(15.6 \pm 9.9)$ notes. Call notes are given at a rate of $4-5(4.2 \pm 0.6)$ per second. Notes last $57-79(66.6 \pm 2.6) \mathrm{ms}$, and the rise time is at $13-73(35.8 \pm 3.2) \%$ of note duration. Notes are formed by $2-3(2.6 \pm 0.5)$ partly fused pulses with duration varying from $10-53(26.4 \pm 6.4) \mathrm{ms}$. Notes have the dominant frequency coinciding almost always with the fundamental harmonic $(1873-2046 \mathrm{~Hz}, 1959.9 \pm 2.3)$, but coinciding with the second 
harmonic $(3596-4156 \mathrm{~Hz}, 3962.1 \pm 254.8)$ in four notes given by the male from Brazil. The frequency modulation is upward, rising from 43-301 (194.0 \pm 12.3$) \mathrm{Hz}$.

The advertisement call of Adenomera simonstuarti (Fig. 5) recorded from the type locality (Camisea, Peru; Angulo \& Icochea 2010) and from Brazil are given as multi-note calls. The multi-note call of A. simonstuarti represents a useful diagnostic character of the species by being unique among members of the A. andreae clade. The only other described species of Adenomera with multi-note call is the allopatric A. cotuba Carvalho \& Giaretta, 2013, distributed in the Cerrado savannas and dry forests of north central Brazil (Carvalho \& Giaretta 2013b). Additionally, the following morphological and color features, when combined with acoustic data, can help distinguish nominal $A$. simonstuarti from the seven Amazonian congeners [A. andreae, A. chicomendesi, A. coca (Angulo \& Reichle, 2008), A. heyeri, A. hylaedactyla, A. lutzi and A. phonotriccus; see Boistel et al. 2006; Kok et al. 2007; Angulo \& Reichle 2008; Carvalho et al. 2019b, 2019c, 2019d]: (1) a nearly solid, dark-colored stripe along the underside of the forearm; (2) absence of dorsolateral stripe; (3) toe tips fully expanded into discs; (4) absence of antebrachial tubercle on underside of forearm; and (5) multi-note advertisement call.

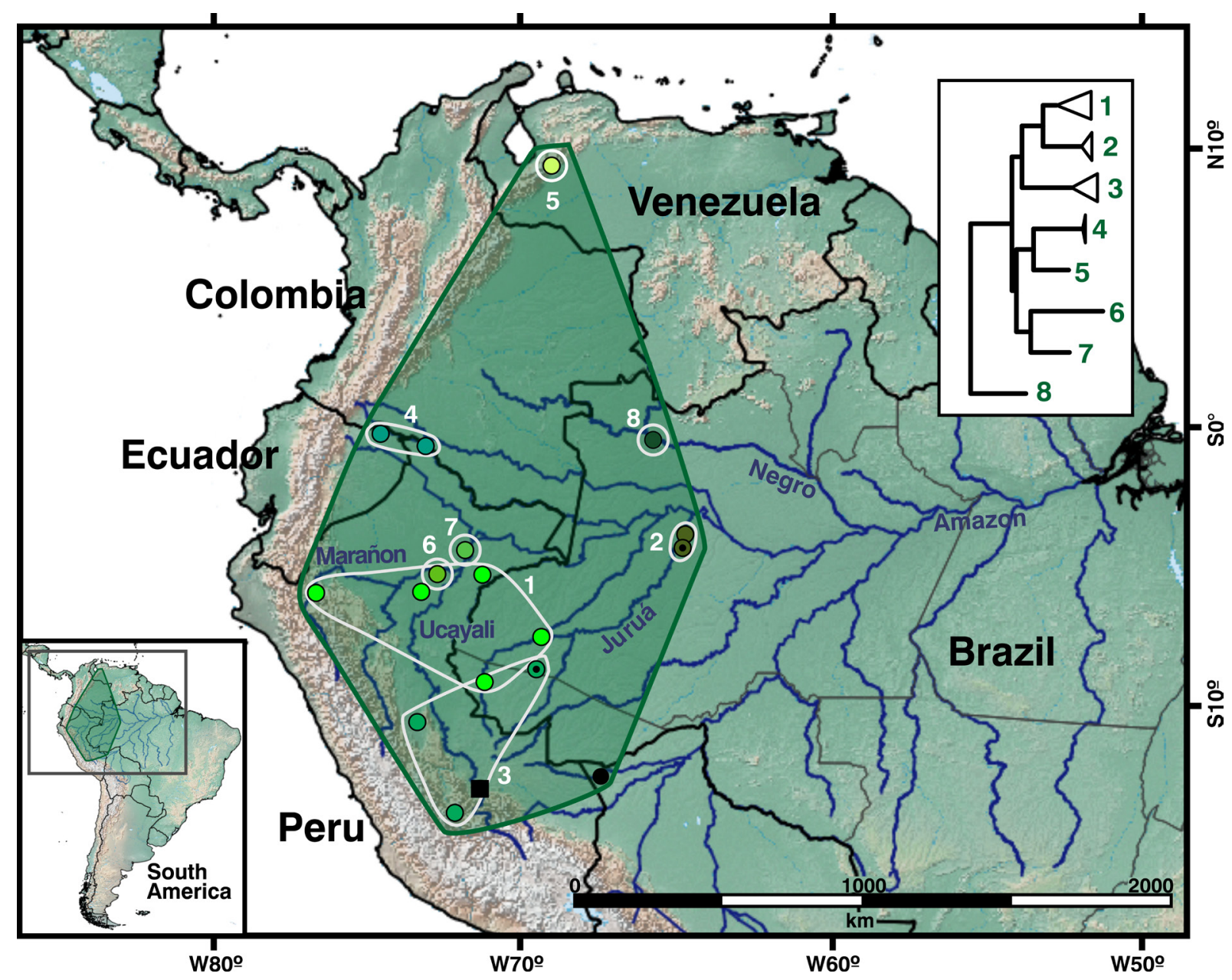

Fig. 2. Geographic distribution of the Adenomera simonstuarti species complex in northwestern South America; genetic lineage 3 corresponds to the nominal species. Phylogenetic relationships among the eight lineages are shown on the upper right. Black solid-filled symbols represent the localities reported in the original description ( square $=$ type locality at Camisea, Peru; circle $=$ Pando, Bolivia). Blackdotted symbols indicate newly collected specimens from the Juruá River in the Brazilian Amazonia. 


\section{Habitat and natural history}

The call voucher of Adenomera simonstuarti from the upper Juruá River (INPA-H 40967; Fig. 3), corresponding to the lineage 3, was collected from an open bamboo forest, approximately $2 \mathrm{~km}$ from BR-364 road. This individual and other two were heard calling from an old clearing surrounded by decomposing fallen logs. The three individuals called hidden underneath dense leaf litter, and only one of them (the call voucher) were found while surveying the area. Adenomera simonstuarti and A. andreae were found syntopically in this area.

The four specimens from the lower Juruá River (INPA-H 39792, 39796 and 39813-14; Fig. 4), corresponding to lineage 2, were collected in a non-flooded lowland forest (terra firme forest) with dense understory layer. Three specimens (INPA-H 39792 and 39813-14) were found in a forest affected by anthropogenic activities (i.e., logging), located close to Comunidade Cumaru village. This could indicate a certain degree of tolerance of the lower Juruá population to habitat disturbance, given that human occupation and activities in this region have begun during the late 1980s (ICMBio 2009). The specimen INPA-H 39796 (Fig. 4) was collected from a preserved forest, distant from that village. Specimens in the lower Juruá River were sympatric with A. andreae and A. hylaedactyla. Adenomera

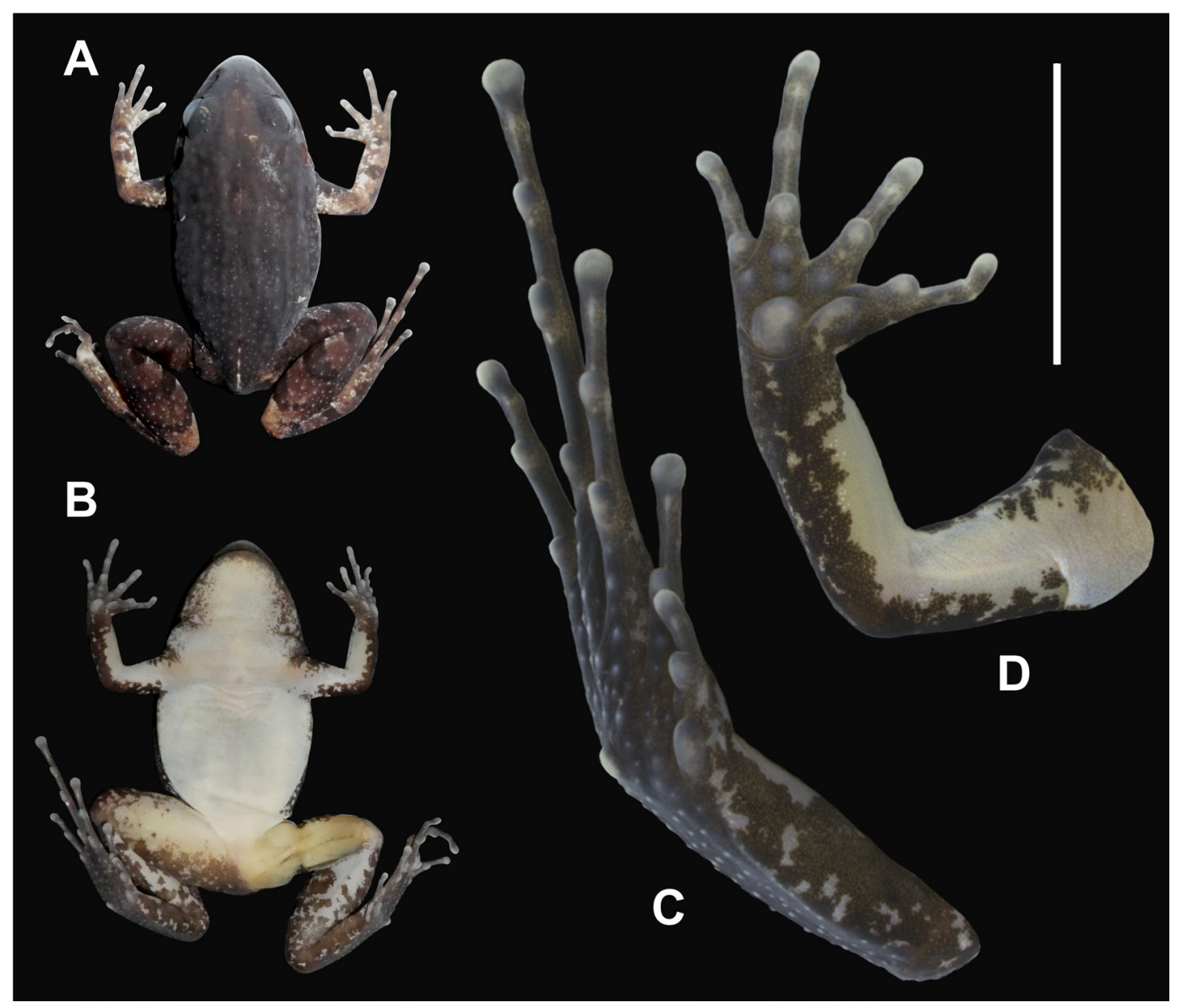

Fig. 3. Preserved male of nominal Adenomera simonstuarti (Angulo \& Icochea, 2010) (= genetic lineage 3): call voucher INPA-H $40967(\mathrm{SVL}=23.4 \mathrm{~mm})$ from the upper Juruá River, in Tarauacá, Brazilian state of Acre. This specimen corresponds to a call voucher (see Fig. 5). A-B. Body in dorsal and ventral views, not to scale. C-D. Detail of the ventral surface of right foot and hand, respectively. Note the nearly solid, dark-colored stripe along the underside of the forearm. Photographs by J. Magnusson. Scale bar $=5 \mathrm{~mm}$. 
simonstuarti and $A$. andreae were found syntopically inside the forest, whereas $A$. hylaedactyla was only found along riverbanks.

\section{Distribution patterns}

Adenomera simonstuarti (= lineage 3) is distributed in the upper Amazon Basin of southwestern Brazilian and Peruvian Amazonia, and two locations in the eastern slopes of the Andes in south central Peru. Populations linked to the other seven lineages are in most cases allopatric among each other. Some lineages are widely distributed, such as lineage 1, from lowland and montane forests in the upper Amazon Basin of Peru and Brazil. Other lineages, such as lineage 2, may be narrowly distributed on the east bank of the lower Juruá River. Other distribution patterns include: lineage 4 in lowland Amazonia of northeastern Ecuador and extreme northern Peru; lineage 5 in Venezuelan Andes montane forests; lineage 6 in the Marañon-Ucayali interfluve; lineage 7 in the upper Amazon River; and lineage 8 in the upper Negro River. Based on the geographic patterns of each of the lineages, we could expect that some of them may have distributions associated with interfluve regions, such as lineages 4, 6 and 7 (Fig. 2). Another interesting pattern is that the nominal species (lineage 3) and other lineages (e.g., lineage 8) are distributed in the upper Amazon Basin, while some others are distributed in the middle-lower portions of major southern tributaries of the Amazon River (e.g., lineage 2; Fig. 2).

\section{Discussion}

We did not examine for the morphological analysis most of the genetic vouchers linked to the Adenomera simonstuarti lineages of Fouquet et al. (2014); see their appendix S1a. The only exception is the specimen
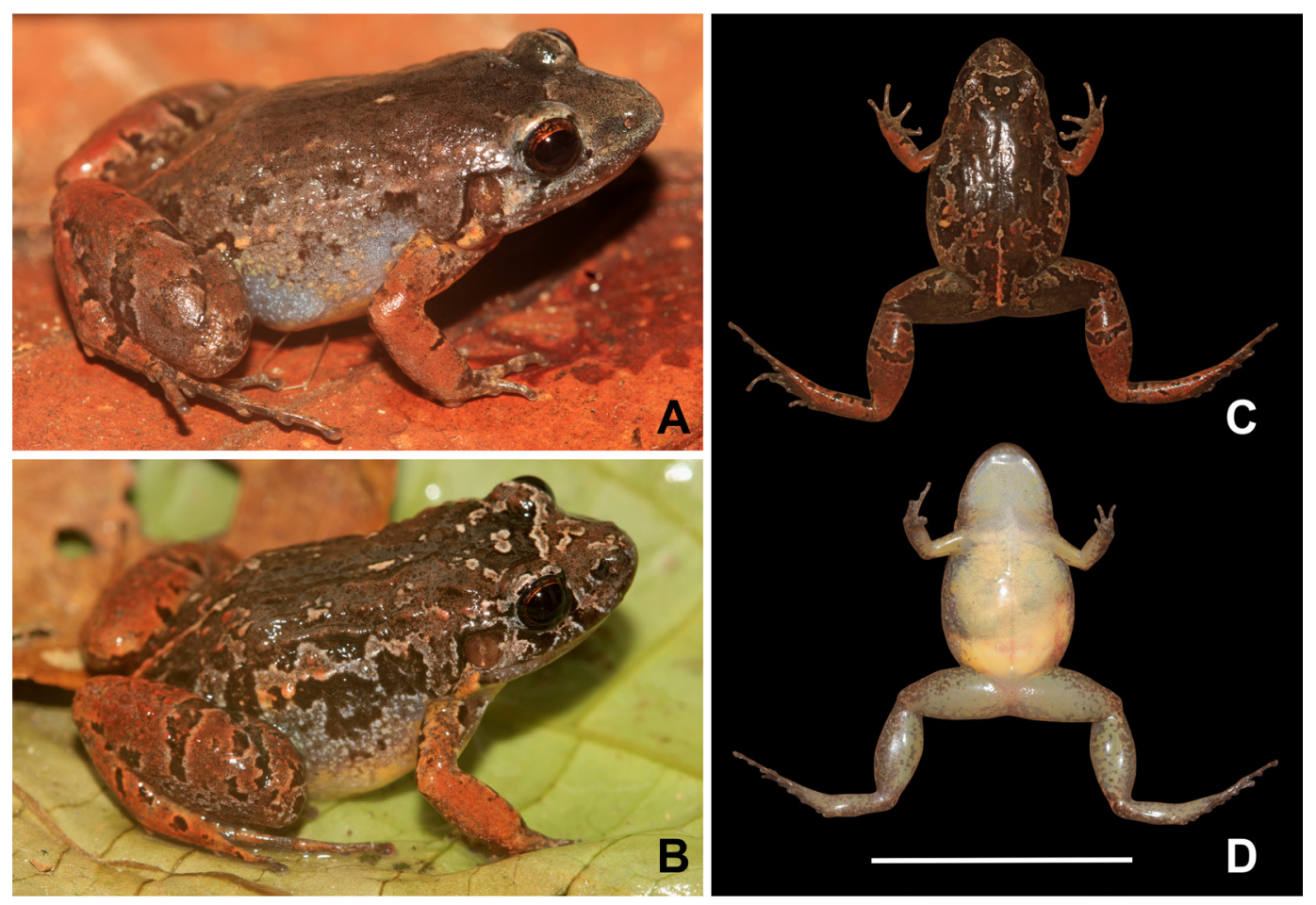

Fig. 4. Specimens of the genetic lineage 2 related to Adenomera simonstuarti (Angulo \& Icochea, 2010) from the lower Juruá River, in Juruá, Brazilian state of Amazonas. A-B. Dorsolateral view of the adult male, $\mathrm{SVL}=22.6 \mathrm{~mm}$ (INPA-H 39792) and the adult female, $\mathrm{SVL}=26.1 \mathrm{~mm}($ INPA-H 39814), respectively. C-D. Dorsal and ventral views of the female shown in B. Photographs by L.J.C.L. Moraes. Scale bar $=25 \mathrm{~mm}$. 
INPA-H 5337 (see Material examined) belonging to the lineage 2 from the lower Juruá River (previously reported as QU5337 by Fouquet et al. 2014). Likewise, acoustic data for the lineages other than the one containing the nominal species remain unknown. Nevertheless, by reinterpreting the calling pattern of $A$. simonstuarti (i.e., multi-note advertisement call) and linking the nominal species to a specific genetic lineage, our study contributes to the potential discrimination between the nominal species and closely related, putative new species within the $A$. simonstuarti complex. Due to the lack of acoustic and morphological data that could help to corroborate the existence of multiple, unnamed lineages within this species complex, a plausible alternative hypothesis would be the one of $A$. simonstuarti as a single species containing deep conspecific lineages across its geographic range in western Amazonia. Future studies should follow the protocol of combining calls and DNA sequences associated with voucher specimens as a means to fully address the taxonomic status of the other seven genetic lineages within the $A$. simonstuarti complex, regarded herein as putative new species.

Of special relevance is the acquisition of DNA sequences for the Amazonian Adenomera population from Camisea, in southeastern Peru, sympatric with $A$. simonstuarti in the type locality region. That population was originally reported as Adenomera cf. andreae by Angulo \& Icochea (2003), but referred hereinafter to as Adenomera sp. from Camisea. Based on the few calls available (recording FNJV 45413; see Fig. 5C-D), we briefly and qualitatively characterized the advertisement call of Adenomera sp. from Camisea as nonpulsed and given as single notes, with the dominant frequency at the fundamental harmonic, and with negligible frequency modulation. These acoustic traits distinguish this taxon from the sympatric A. simonstuarti and all other Amazonian species of Adenomera (for acoustic comparisons in Adenomera, see Carvalho et al. 2019b, 2019c, 2019d). We also examined the recorded male of Adenomera sp. from Camisea (accession number: MUSM 18219), which differs from nominal A. simonstuarti by lacking the nearly solid, black-colored stripe along the underside of the forearm. In fact, the specimen is morphologically more similar to other members of the $A$. andreae clade, especially by the presence of toe tips fully expanded into small discs (Carvalho et al. 2019b, 2019d). Based on its distinctive call, however, Adenomera sp. from Camisea cannot be conspecific with nominal A. andreae or any other described species and candidate new species of the $A$. andreae clade with described calls
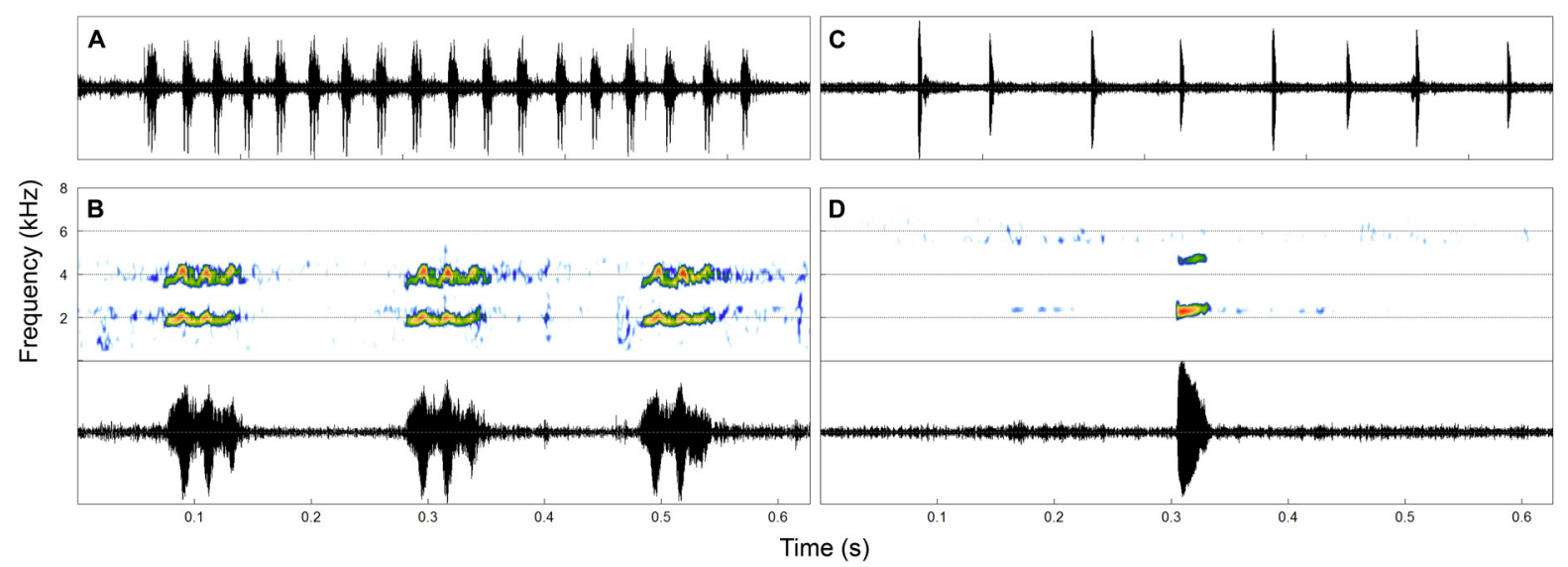

Fig. 5. Advertisement calls of (A-B) nominal Adenomera simonstuarti (Angulo \& Icochea, 2010) (= genetic lineage 3) from the upper Juruá River, in southwestern Amazonia of the Brazilian state of Acre (voucher INPA-H 40976), and (C-D) the sympatric Adenomera sp. from Camisea, in the Region of Cusco, Peru (voucher MUSM 18219). A. Time-domain section containing a multi-note call (18 notes). B. Spectrogram and oscillogram of three notes $\left(5^{\text {th }}-7^{\text {th }}\right)$ from the call in A. C. Time-domain section of two males in antiphonal calling (single-note calls). D. Spectrogram and oscillogram of the $4^{\text {th }}$ note in C. Figures are equally scaled (ca $4.5 \mathrm{~s}$ on the $\mathrm{x}$-axis of $\mathrm{A}$ and $\mathrm{C}$, each marking corresponding to $1.0 \mathrm{~s}$ ). 
(Angulo et al. 2003; Carvalho et al. 2019b, 2019d), except for two Peruvian lineages (i.e., Adenomera sp. D and Adenomera sp. T; Fouquet et al. 2014) whose calls remain unknown (for further discussion, see Fouquet et al. 2014: appendix S2a). Adenomera sp. from Camisea should therefore correspond to an unnamed species that may be conspecific with one of the two candidate new species of the $A$. andreae clade with unknown calls (Adenomera sp. D and Adenomera sp. T), with one of the lineages under A. simonstuarti for which morphological data have not yet been assessed, or might even have not been genetically sampled to date.

The age of initial diversification of the Adenomera simonstuarti complex is unknown but likely during the Miocene, given that the divergence time between this species complex and its sister clade (A. chicomendesi + Adenomera sp. D) was estimated to have occurred during this geological period (8.0-8.5 Ma; Fouquet et al. 2014). The A. simonstuarti complex inhabits an Amazonian region that has been affected by several landscape changes and hydrological instability during the Miocene (Albert et al. 2018), which might have generated the deep genetic divergence that mirrors the allopatric distributions of lineages within the complex (Figs 1-2). Furthermore, the result of intense climatic variation in the region during the Pleistocene, which modified the extension and structure of the forest habitats in the region (Arruda et al. 2018), might also have contributed to the more recent divergences within this complex.

The southwestern lowland Amazonian forests consist of a heterogeneous mosaic of habitats. We surveyed for Adenomera in flooded forests (várzeas) and other riparian environments, but individuals of the A. simonstuarti complex were only found in non-flooded (terra firme) forest. These non-flooded forests are patchily distributed within the heterogeneous landscape, in some cases distantly located from the main course of rivers, which are the primary access route by researchers (Oliveira et al. 2016). For this reason, the limited access to the apparently preferred habitat may bias the understanding of the geographic range and patterns of distribution of lineages within the A. simonstuarti complex. The conservation status of $A$. simonstuarti was originally assessed as Data Deficient (DD), pending future surveys to confirm that it could also occur in between known localities of Peru and Bolivia (Angulo \& Icochea 2010). With the inclusion of the new occurrence record in the Brazilian state of Acre (Fig. 2), the putative distribution of nominal $A$. simonstuarti is extended northward and the estimated Extent of Occurrence (EOO; IUCN 2012) is approximately $200000 \mathrm{~km}^{2}$ (sensu Bachman et al. 2011). Given the new estimated EOO, encompassing conservation units, and the fact that populations of $A$. simonstuarti appear to tolerate certain degree of habitat disturbance (Angulo \& Icochea 2010; present study), we recommend that the extinction risk of nominal A. simonstuarti could be assessed as Least Concern (LC) following the IUCN Red List Categories and Criteria (IUCN 2012). The reassessment of extinction risk should only be taken into account, however, as long as the region does not suffer from severe impacts caused by human activities in the near future, including the indirect action of anti-environmental public policies, such as the recent fire crisis and illegal operations that have taken place across Amazonia (Ferrante \& Fearnside 2019; Pereira \& Viola 2019; Barlow et al. 2020).

Despite the recommendation of extinction risk of nominal Adenomera simonstuarti in the Least Concern category, it is important to highlight the potential threats and extinction risk to the other seven lineages subsumed within the $A$. simonstuarti complex, regarded as putative new species. This is especially relevant because conservation strategies are in many cases not feasible as long as the taxonomic status of unnamed lineages is not fully resolved; see Angulo \& Icochea (2010) for a proposition on the impacts of cryptic species complexes on biodiversity and conservation assessments. By circumscribing A. simonstuarti to one of eight genetic lineages within the complex, its distribution is dramatically narrowed down to the southernmost portion of the entire range of the species complex $\left(\sim 2\right.$ million $\mathrm{km}^{2}$ EOO; Fig. 2), corresponding to a decrease of $90 \%$ in EOO. Our current knowledge on species richness and distribution is still insufficient for accurate evaluations of conservation status and distribution patterns 
of the A. simonstuarti complex. In the opposite scenario, by lumping the other seven lineages back into A. simonstuarti and considering the deep genetic divergence as intraspecific variation, the conservation of metapopulations displaying high genetic variability should also be taken into consideration as a significant component to safeguard the biological heritage (Crandall et al. 2000).

\section{Acknowledgements}

This work was supported by Fundação de Amparo à Pesquisa do Estado de São Paulo through a postdoctoral fellowship (FAPESP \#2017/08489-0 to TRC), Conselho Nacional de Desenvolvimento Científico e Tecnológico (CNPq) through a research and productivity fellowships (\#313055/2015-7 to LJCLM; \#475559/2013-4, \#425571/2018-1 and \#305535/2017-0 to FPW; and \#401120/2016-3 and \#307607/2015-1 to APL), Fundação de Amparo à Pesquisa do Estado do Amazonas (FAPEAM) through an internship and research fellowships (062.00962/2018 to LJCLM; \#062.00665/2015, \#062.01110/2017 and \#062.00962/2018 to FPW), Partnerships for Enhanced Engagement in Research from the U.S. National Academy of Sciences and U.S. Agency of International Development (FPW PEER NAS/USAID AID-OAA-A-11-00012, cycle 3), and L'Oréal-Unesco For Women in Science Program (FPW Brazil/ ABC 2016, IRT 2017). The field expedition to the lower Juruá River was organized and undertaken by the Instituto de Desenvolvimento Sustentável Mamirauá and Instituto Chico Mendes de Conservação da Biodiversidade (ICMBio), with financial support from Gordon and Betty Moore Foundation. We thank A. Oliveira, R. Rainha, and members of Instituto Mamirauá and Comunidade Cumaru for their help during fieldwork. The following individuals granted access to specimens under their care: A. Silva (INPA-H), A.A. Giaretta (AAG-UFU), N. Pupin and D.B. Delgado (CFBH), L.F. Toledo and K. Rabelo (ZUEC), A.L.C. Prudente and F. Sarmento (MPEG), T. Grant and A.S. Benetti (MZUSP), C. AguilarPuntriano (MUSM). Collecting permits were issued by the Brazilian government (SISBIO/ICMBio \#62798-2, \#13777-2).

\section{References}

Albert J.S., Val P. \& Hoorn C. 2018. The changing course of the Amazon River in the Neogene: center stage for Neotropical diversification. Neotropical Ichthyology 16: e180033.

https://doi.org/10.1590/1982-0224-20180033

Angulo A. \& Icochea J. 2003. Adenomera cf. andreae (NCN): vocalization. Herpetological Review 34: $47-48$.

Angulo A. \& Icochea J. 2010. Cryptic species complexes, widespread species and conservation: lessons from Amazonian frogs of the Leptodactylus marmoratus group (Anura: Leptodactylidae). Systematics and Biodiversity 8: 357-370. https://doi.org/10.1080/14772000.2010.507264

Angulo A. \& Reichle S. 2008. Acoustic signals, species diagnosis, and species concepts: the case of a new cryptic species of Leptodactylus (Amphibia, Anura, Leptodactylidae) from the Chapare Region, Bolivia. Zoological Journal of the Linnean Society 152: 59-77.

https://doi.org/10.1111/j.1096-3642.2007.00338.x

Angulo A., Cocroft R.B. \& Reichle S. 2003. Species identity in the genus Adenomera (Anura: Leptodactylidae) in southeastern Peru. Herpetologica 59: 490-504. https://doi.org/10.1655/20-104

Arruda D.M., Schaefer C.E.G.R., Fonseca R.S., Solar R.R.C. \& Fernandes-Filho E.I. 2018. Vegetation cover of Brazil in the last $21 \mathrm{ka}$ : new insights into the Amazonian refugia and Pleistocenic arc hypotheses. Global Ecology and Biogeography 27: 47-56. https://doi.org/10.1111/geb.12646

Audacity Team. 2017. Audacity(R): Free Audio Editor and Recorder. Ver. 2.1.1. Available from https://audacityteam.org [accessed 5 May 2018]. 
Bachman S., Moat J., Hill A.W., De la Torre J. \& Scott B. 2011. Supporting red list threat assessments with GeoCAT: geospatial conservation assessment tool. ZooKeys 150: 117-126. https://doi.org/10.3897/zookeys.150.2109

Barlow J., Berenguer E., Carmenta R. \& França F. 2020. Clarifying Amazonia's burning crisis. Global Change Biology 26: 319-321. https://doi.org/10.1111/gcb.14872

Bickford D., Lohman D.J., Sodhi S., Ng K., Meier R., Winker K., Ingram K.K. \& Das I. 2007. Cryptic species as a window on diversity and conservation. Trends in Ecology and Evolution 22: 148-155. https://doi.org/10.1016/j.tree.2006.11.004

Boistel R., Massary J.-C. \& Angulo A. 2006. Description of a new species of the genus Adenomera (Amphibia, Anura, Leptodactylidae) from French Guiana. Acta Herpetologica 1: 1-14. https://doi.org/10.13128/Acta_Herpetol-1249

Carvalho T.R. \& Giaretta A.A. 2013a. Taxonomic circumscription of Adenomera martinezi (Bokermann, 1956) (Anura: Leptodactylidae: Leptodactylinae) with the recognition of a new cryptic taxon through a bioacoustic approach. Zootaxa 3701: 207-237. https://doi.org/10.11646/zootaxa.3701.2.5

Carvalho T.R. \& Giaretta A.A. 2013b. Bioacoustics reveals two new syntopic species of Adenomera Steindachner (Anura: Leptodactylidae: Leptodactylinae) in the Cerrado of central Brazil. Zootaxa 3731: 533-551. https://doi.org/10.11646/zootaxa.3731.4.6

Carvalho T.R., Cassini C.S., Taucce P.P.G. \& Haddad C.F.B. 2019a. A new, morphologically cryptic species of Adenomera closely related to A. araucaria from the Atlantic Forest of southern Brazil (Anura, Leptodactylidae). Journal of Herpetology 53: 131-143. https://doi.org/10.1670/18-172

Carvalho T.R., Angulo A., Kokubum M.N.C., Barrera D.A., Souza M.B., Haddad C.F.B. \& Giaretta A.A. 2019b. A new cryptic species of the Adenomera andreae clade from southwestern Amazonia (Anura, Leptodactylidae). Herpetologica 75: 233-246. https://doi.org/10.1655/D-18-00049

Carvalho T.R., Giaretta A.A., Angulo A., Haddad C.F.B. \& Peloso P.L.V. 2019c. A new Amazonian species of Adenomera (Anura: Leptodactylidae) from the Brazilian state of Pará: a tody-tyrant voice in a frog. American Museum Novitates 3919: 1-21. https://doi.org/10.1206/3919.1

Carvalho T.R., Giaretta A.A., Maciel N.M., Barrera D.A., Aguilar-Puntriano C., Haddad C.F.B., Kokubum M.N.C., Menin M. \& Angulo A. 2019d. On the uncertain taxonomic identity of Adenomera hylaedactyla (Cope, 1868) and the composite type series of $A$. andreae (Müller, 1923) (Anura, Leptodactylidae). Copeia 107: 708-723. https://doi.org/10.1643/CH-19-237

Cassini C.S., Taucce P.P.G., Carvalho T.R., Fouquet A., Solé M., Haddad C.F.B. \& Garcia P.C.A. 2020. One step beyond a broad molecular phylogenetic analysis: species delimitation of Adenomera marmorata Steindachner, 1867 (Anura: Leptodactylidae). PLoS ONE 15: e0229324.

https://doi.org/10.1371/journal.pone.0229324

Che J., Chen H.M., Yang J.X., Jin J.Q., Jiang K.E., Yuan Z.Y., Murphy R.W. \& Zhang Y.P. 2012. Universal COI primers for DNA barcoding amphibians. Molecular Ecology Resources 12: 247-258. https://doi.org/10.1111/j.1755-0998.2011.03090.x

Cherty L.M., Case S.M. \& Wilson A.C. 1978. Frog perspective on morphological difference between humans and chimpanzees. Science 200: 209-211. https://doi.org/10.1126/science.635583

Clark K., Karsch-Mizrachi I., Lipman D.J., Ostell J. \& Sayers E.W. 2016. GenBank. Nucleic Acids Research 44: D67-D72. https://doi.org/10.1093/nar/gkv1276

Crandall K.A., Bininda-Emonds O.R.P., Mace G.M. \& Wayne R.K. 2000. Considering evolutionary processes in conservation biology. Trends in Ecology \& Evolution 15: 290-295.

https://doi.org/10.1016/S0169-5347(00)01876-0 
Ferrante L. \& Fearnside P.M. 2019. Brazil's new president and 'ruralists' threaten Amazonia's environment, traditional peoples and the global climate. Environmental Conservation 46: 261-263. https://doi.org/10.1017/S0376892919000213

Fouquet A., Gilles A., Vences M., Marty C., Blanc M. \& Gemmel N.J. 2007. Underestimation of species richness in Neotropical frogs revealed by mtDNA analysis. PLoS ONE 10: e1109.

https://doi.org/10.1371/journal.pone.0001109

Fouquet A., Cassini C.S., Haddad C.F.B., Pech N. \& Rodrigues M.T. 2014. Species delimitation, patterns of diversification and historical biogeography of the Neotropical frog genus Adenomera (Anura, Leptodactylidae). Journal of Biogeography 41: 855-870. https://doi.org/10.1111/jbi.12250

Fouquet A., Martinez Q., Zeidler L., Courtois E.A., Gaucher P., Blanc M., Lima J.D., Souza S.M., Rodrigues M.T. \& Kok P.J.R. 2016. Cryptic diversity in the Hypsiboas semilineatus species group (Amphibia, Anura) with the description of a new species from the eastern Guiana Shield. Zootaxa 4084: 79-104. https://doi.org/10.11646/zootaxa.4084.1.3

Gridi-Papp M. 2007. Soundruler: Acoustic Analysis for Research and Teaching. Ver. 0.9.6.1. Available from http://soundruler.sourceforge.net [accessed 5 May 2018].

Hurvich C.M. \& Tsai C.-L. 1989. Regression and time series model selection in small samples. Biometrika 76: 297-307. https://doi.org/10.1093/biomet/76.2.297

ICMBio. 2009. Plano de Manejo: Reserva Extrativista do Baixo Juruá, Brazil. Ministério Do Meio Ambiente. Available from

servacao/biomas-brasileiros/amazonia/unidades-de-conservacao-amazonia/2012-resex-do-baixo-jurua [accessed 4 Dec. 2019].

IUCN. 2012. IUCN Red List Categories and Criteria. Ver. 3.1. $2^{\text {nd }}$ Ed. IUCN, Gland.

Jungfer K-H., Faivovich J., Padial J.M., Castroviejo-Fisher S., Lyra M.M., Berneck B.V.M., Iglesias P.P., Kok P.J.R., Macculloch R.D., Rodrigues M.T., Verdade V.K., Gastello C.P.T., Chaparro J.C., Valdujo P.H., Reichle S., Moravec J., Gvoždík V., Gagliardi-Urrutia G., Ernst R., De la Riva I., Means D.B., Lima A.P., Señaris C., Wheeler W.C. \& Haddad C.F.B. 2013. Systematics of spiny-backed treefrogs (Hylidae: Osteocephalus): an Amazonian puzzle.Zoologica Scripta 42:351-380. https://doi.org/10.1111/zsc.12015

Katoh K. \& Standley D.M. 2013. MAFFT multiple alignment software version 7: improvements in performance and usability. Molecular Biology and Evolution 30: 772-780.

https://doi.org/10.1093/molbev/mst010

Kearse M., Moir R., Wilson A., Stones-Havas S., Cheung M., Sturrock S., Buxton S., Cooper A., Markowitz S., Duran C., Thierer T., Meintjes P. \& Drummond A. 2012. Geneious Basic: an integrated and extendable desktop software platform for the organization and analysis of sequence data. Bioinformatics 28: 1647-1649. https://doi.org/10.1093/bioinformatics/bts199

Kok P.J.R., Kokubum M.N.C., MacCulloch R.D. \& Lathrop A. 2007. Morphological variation in Leptodactylus lutzi (Anura, Leptodactylidae) with description of its advertisement call and notes on its courtship behavior. Phyllomedusa, Journal of Herpetology 6: 45-60.

https://doi.org/10.11606/issn.2316-9079.v6ilp45-60

Kumar S., Stecher G. \& Tamura K. 2016. MEGA7: molecular evolutionary genetics analysis version 7.0 for bigger datasets. Molecular Biology and Evolution 33: 1870-1874.

https://doi.org/10.1093/molbev/msw054

Lanfear R., Frandsen P.B., Wright A.M., Senfeld T. \& Calcott B. 2017. PartitionFinder 2: new methods for selecting partitioned models of evolution for molecular and morphological phylogenetic analyses. Molecular Biology and Evolution 34: 772-773. https://doi.org/10.1093/molbev/msw260 
Ligges U., Krey S., Mersmann O. \& Schnackenberg S. 2017. tuneR: analysis of music and speech. Ver. 1.3.2. Available from https://CRAN.R-project.org/package=tuneR [accessed 5 May 2018].

Lyra M.L., Haddad C.F.B. \& Azeredo-Espin A.M.L. 2017. Meeting the challenge of DNA barcoding amphibians from Neotropics: polymerase chain reaction optimization and new COI primers. Molecular Ecology Resources 17: 966-980. https://doi.org/10.1111/1755-0998.12648

Matlab. 2004. The Language of Technical Computing. Ver. 6.5.2. MathWorks, Inc., Natick.

Oliveira U., Paglia A.P., Brescovit A.D., Carvalho C.J.B., Silva D.P., Rezende D.T., Leite F.S.F., Batista J.A.N., Barbosa J.P.P.P., Stehmann J.R., Ascher J.S., Vasconcelos M.R., Marco Jr. P., LöwenbergNeto P., Dias P.G., Ferro V.G. \& Santos A.J. 2016. The strong influence of collection bias on biodiversity knowledge shortfalls of Brazilian terrestrial biodiversity. Diversity and Distributions 22: 1-13. https://doi.org/10.1111/ddi.12489

Padial J.M. \& De la Riva I. 2009. Integrative taxonomy reveals cryptic Amazonian species of Pristimantis (Anura: Strabomantidae). Zoological Journal of the Linnean Society 155: 97-122. https://doi.org/10.1111/j.1096-3642.2008.00424.x

Padial J.M., Miralles A.D., De la Riva I. \& Vences M. 2010. The integrative future of taxonomy. Frontiers in Zoology 7: e16. https://doi.org/10.1186/1742-9994-7-16

Pereira J.C. \& Viola E. 2019. Catastrophic climate risk and Brazilian Amazonian politics and policies: a new research agenda. Global Environmental Politics 19: 93-103. https://doi.org/10.1162/glep_a_00499

Puillandre N., Lambert A., Brouillet S. \& Achaz G. 2012. ABGD, Automatic Barcode Gap Discovery for primary species delimitation. Molecular Ecology 21: 1864-1877.

https://doi.org/10.1111/j.1365-294X.2011.05239.x

R Core Team. 2018. R: A Language and Environment for Statistical Computing. Ver. 3.5.0. R Foundation for Statistical Computing, Vienna. Available from http://www.r-project.org [accessed 4 May 2018].

Rambaut A., Drummond A.J., Xie D., Baele G. \& Suchard M.A. 2018. Posterior summarisation in Bayesian phylogenetics using Tracer 1.7. Systematic Biology 67: 901-904.

https://doi.org/10.1093/sysbio/syy032

Ronquist F., Teslenko M., van der Mark P., Ayres D.L., Darling A., Höhna S., Larget B., Liu L., Suchard M.A. \& Huelsenbeck J.P. 2012. MrBayes 3.2: efficient Bayesian phylogenetic inference and model choice across a large model space. Systematic Biology 61: 539-542.

https://doi.org/10.1093/sysbio/sys029

Sabaj M.H. 2019. Standard Symbolic Codes for Institutional Resource Collections in Herpetology and Ichthyology: An Online Reference. Ver. 7.1. Available from https://asih.org/standard-symbolic-codes/about-symbolic-codes [accessed 4 Dec. 2019].

Simões P.I., Lima A.P. \& Farias I.P. 2010. The description of a cryptic species related to the panAmazonian frog Allobates femoralis (Boulenger 1883) (Anura: Aromobatidae). Zootaxa 2406: 1-28. https://doi.org/10.11646/zootaxa.2406.1.1

Stamatakis A. 2014. RAxML version 8: a tool for phylogenetic analysis and post-analysis of large phylogenies. Bioinformatics 30: 1312-1313. https://doi.org/10.1093/bioinformatics/btu033

Sueur J., Aubin T. \& Simonis C. 2008. Seewave: a free modular tool for sound analysis and synthesis. Bioacoustics, The International Journal of Animal Sound and its Recording 18: 213-226. https://doi.org/10.1080/09524622.2008.9753600

Tavaré S. 1986. Some probabilistic and statistical problems in the analysis of DNA sequences. Lectures on Mathematics in the Life Sciences 17: 57-86. 
Manuscript received: 9 April 2020

Manuscript accepted: 26 May 2020

Published on: 8 July 2020

Topic editor: Rudy Jocqué

Desk editor: Pepe Fernández

Printed versions of all papers are also deposited in the libraries of the institutes that are members of the EJT consortium: Muséum national d'histoire naturelle, Paris, France; Meise Botanic Garden, Belgium; Royal Museum for Central Africa, Tervuren, Belgium; Royal Belgian Institute of Natural Sciences, Brussels, Belgium; Natural History Museum of Denmark, Copenhagen, Denmark; Naturalis Biodiversity Center, Leiden, the Netherlands; Museo Nacional de Ciencias Naturales-CSIC, Madrid, Spain; Real Jardín Botánico de Madrid CSIC, Spain; Zoological Research Museum Alexander Koenig, Bonn, Germany; National Museum, Prague, Czech Republic.

\section{Supplementary File}

SM.01. GenBank accession numbers and locality data of genetic vouchers included in this study. New sequences are indicated in bold. 